\title{
Triiodothyronine Enhances Expression of the Interleukin-2 Receptor Alpha Chain
}

\author{
KIMIo NAKANISHI, YoshIYASU TANIGUCHI aND MoRIKAZU ONJI
}

The Third Department of Internal Medicine, Ehime University School of Medicine, Ehime, Japan

\begin{abstract}
The effect of thyroid hormone on immune function is unclear. The influence of L-triiodothyronine on expression of the interleukin-2 receptor alpha chain by peripheral blood mononuclear cells from healthy volunteers and YT cells (an interleukin-2 independent natural killer-like cell line) was examined. Concanavalin A stimulation significantly $(\mathrm{p}<0.05$ and $\mathrm{p}<0.01)$ increased soluble interleukin-2 receptor alpha chain production when mononuclear cells were cultured with triiodothyronine $(1-100 \mathrm{nmol} / \mathrm{l})$ for 3 days. The stimulatory effect of triiodothyronine on interleukin-2 receptor alpha chain expression was greater in the presence of concanavalin A $(5 \mu \mathrm{g} / \mathrm{ml})$ plus interleukin-2 $(1 \mathrm{U} / \mathrm{ml})$ than in the presence of concanavalin A alone. Triiodothyronine also significantly $(\mathrm{p}<0.01)$ increased interleukin-2 receptor alpha chain expression when YT cells were cultured for 2 days with interleukin-2 $(1 \mathrm{U} / \mathrm{ml})$, but did not influence receptor expression when YT cells were cultured with forskolin or 12O-tetradecanoyl phorbol 13-acetate, potent activators of signal transduction. In conclusion, triiodothyronine may have an immunomodulatory effect by enhancing expression of the interleukin-2 receptor alpha chain on peripheral blood mononuclear cells in the presence of interleukin-2.
\end{abstract}

Key words: Interleukin-2 receptor alpha chain, Soluble interleukin-2 receptor, L-triiodothyronine

(Endocrine Journal 46: 437-442, 1999)

THYROID hormone has various actions related to the morphogenesis of the central nervous system, amphibian metamorphosis, metabolism, and protein synthesis or degradation [1]. Thyroid hormone also has immunomodulatory effects because hyperthyroidism increases the size of the thymus [2] and changes in thyroid function modify the level of thymulin [3], which is one of the thymic hormones and plays an important role in $\mathrm{T}$ cell ontogeny. Moreover, thyroid hormone is reported to influence lymphocyte subsets $[4,5]$, natural killer cell activity [6], and macrophage inflammatory activity [7]. But because some studies have found no effect on the immune system $[8,9]$, the immunomodulatory effect of thyroid hormone is still uncertain.

Received: October 14, 1998

Accepted: March 12, 1999

Correspondence to: Kimio NAKANISHI, M.D., The Third Department of Internal Medicine, Ehime University School of Medicine, Shigenobu, Onsen-Gun, Ehime, Japan
The interleukin-2 (IL-2)/IL-2 receptor (IL-2R) system plays a central role in immune function by participating in the activation of $\mathrm{T}$ cells and by stimulating their proliferation $[10,11]$. With regard to the influence of thyroid hormone on the IL-2/IL$2 \mathrm{R}$ system, $\mathrm{T}_{3}$ has been shown to enhance IL-2R alpha chain expression by lectin-activated splenocytes from Xenopus laevis and Cornell K chickens $[12,13]$, but does not alter IL-2R alpha chain expression in rats [5].

The soluble IL-2R (sIL-2R) alpha chain is released from receptors on the surface of activated $T$ cells [14] and is a useful marker of the development of various diseases [15-17]. We and other investigators have found a good correlation between the serum thyroid hormone level and the sIL-2R level in patients with untreated Graves' disease [15, 18, 19], and serum sIL-2R is increased by administration of triiodothyronine to healthy volunteers or to patients with Graves' disease in remission [15]. This suggests that thyroid hormone may have an immunomodulatory 
effect by acting through the IL-2/IL-2R system.

It is known that various substances, such as interleukin-1 (IL-1), IL-2, tumor necrosis factor and forskolin, can induce IL-2R alpha chain expression by YT cells $[20,21]$, a natural killer-like leukemic cell line that constitutively expresses the IL-2R beta chain [22].

The purpose of the present study was to examine whether thyroid hormone could induce IL-2R alpha chain expression by YT cells and by peripheral blood lymphocytes.

\section{Materials and Methods}

\section{Chemicals}

L-triiodothyronine $\left(\mathrm{T}_{3}\right)$, forskolin, 12-Otetradecanoyl phorbol 13-acetate (TPA), and bovine serum albumin were purchased from Sigma Chemical Co. (St. Louis, MO). RPMI-1640 medium and fetal bovine serum were obtained from Flow Laboratories (Irvine, Scotland). Concanavalin A (Con A) was obtained from Difco Laboratories (Detroit, MI). Ficoll 400 was purchased from Pharmacia (Uppsala, Sweden). ${ }^{3} \mathrm{H}$-thymidine $(29 \mathrm{Ci} / \mathrm{mmol})$ was obtained from Amersham International plc. (Buckinghamshire, UK). Fetal bovine serum was treated with AGX-8 resin (200-400 mesh, chloride form; Bio-Rad Laboratories, Richmond, CA) by the method of Samuels et al. [23]. $\mathrm{T}_{3}$ was dissolved in $0.1 \mathrm{~N} \mathrm{NaOH}$ and diluted with culture medium (RPMI-1640 containing 10\% resin-treated fetal bovine serum). Forskolin and TPA were dissolved in dimethyl sulfoxide and ethanol, respectively, and were diluted with the culture medium. Recombinant IL-2 was kindly provided by Takeda Chemical Industries Ltd. (Osaka, Japan).

\section{Cell culture}

Human peripheral blood mononuclear cells (PBMC) were obtained from the heparinized venous blood of healthy volunteers by Ficoll-Conray (1.077 $\mathrm{kg} / \mathrm{l})$ gradient centrifugation at $400 \times \mathrm{G}$ for $30 \mathrm{~min}$ at $4^{\circ} \mathrm{C}$. The leukocyte-enriched interface was washed three times in Hanks' balanced salt solution (pH 7.2) and the cells were resuspended in culture medium at $1 \times 10^{6} / \mathrm{ml}$ in 24-well plates (Sumitomo Bakelite Co.,
Ltd., Tokyo, Japan). Culture was performed at $37^{\circ} \mathrm{C}$ under a humidified atmosphere of $5 \% \mathrm{CO}_{2}$ in air, and the cells were stimulated by Con $\mathrm{A}$ and/or IL-2 with or without various concentrations of $T_{3}$ (1-100 nmol/l). YT cells are IL-2-independent natural killer-like cells that were established from a patient with thymic lymphoma, and were a kind gift from Dr. Yodoi (Institute for Virus Research, Kyoto University, Kyoto, Japan) [20]. YT cells were maintained in culture medium at $5 \times 10^{4} / \mathrm{ml}$ with IL-2, TPA, or forskolin in the presence or absence of $\mathrm{T}_{3}$. The healthy volunteers who donated PBMC gave their informed consent before being enrolled in the study.

\section{Proliferation studies}

PBMC and YT cells were suspended at $1 \times 10^{6} / \mathrm{ml}$ and $5 \times 10^{4} / \mathrm{ml}$, respectively, in culture medium, and equal volumes $(200 \mu \mathrm{l})$ of each cell suspension were placed in quadriplicate into 96-well culture plates (Becton-Dickinson Labware, Bridgewater, NJ). To assess the proliferative response, $0.5 \mu \mathrm{Ci}$ of ${ }^{3} \mathrm{H}$ thymidine was added to each well and incubation was continued for 6 hours. Then the wells were harvested (Lab Mash; Ltd., Tokyo, Japan) onto glass fiber filters and the incorporation of thymidine was determined as counts per minute (cpm) in a liquid scintillation counter (Aloka Co. Ltd., Tokyo, Japan).

\section{Measurement of soluble $I L-2$ receptor alpha chain in culture supernatants}

Soluble IL-2 receptor alpha chain levels were measured by an enzyme-linked immunosorbent assay with a CELLFREE Interleukin-2 Receptor kit ( $\mathrm{T}$ cell Science Inc., Cambridge, MA), as described previously [15]. The assay employed a primary anti-IL$2 \mathrm{R}$ monoclonal antibody adsorbed onto the wells and a horseradish peroxidase-conjugated secondary antiIL-2R monoclonal antibody. The absorbance was measured at $490 \mathrm{~nm}$.

\section{$I L-2$ receptor alpha chain detection by flowcyto- metry}

Cells were washed and resuspended in RPMI-1640 supplemented with $10 \%$ fetal bovine serum. Then the cells were incubated for $30 \mathrm{~min}$ at $4{ }^{\circ} \mathrm{C}$ with a 
fluorescein isothiocyanate-conjugated anti-Tac monoclonal antibody (Coulter Co., Hialeath, FL) under saturating conditions in the presence of a 100 -fold excess of human gamma globulin (Organo Teknika Co., West Chester, PA) to block Fc receptors for IgG. After washing in phosphate-buffered saline containing $0.1 \%$ bovine serum albumin and sodium azide, all samples were suspended in $200 \mu$ l of the same buffer and $10^{4}$ cells were analyzed by laser flowcytometry (EPICS Division; Coulter Co., Hialeah, FL). Irrelevant IgG2a antibodies were used as the negative controls with the window set so that less than 5\% control cells were positive. Analysis of IL-2R expression was performed by calculating the percentage of IL-2R positive cells in the case of YT cells or by determining the mean fluorescence intensity (MFI) of stained cells in the case of PBMC, because a large number of PBMC became positive.

\section{Statistical analysis}

Statistical analysis of the data was performed by the paired $t$ test or Wilcoxon test, and $\mathrm{p}<0.05$ was considered to indicate a significant difference. Results are shown as the mean \pm standard deviation.

\section{Results}

Soluble IL-2 receptor alpha chain levels in culture supernatants

The sIL-2R level in culture supernatants from Con A-stimulated PBMC increased over time from day 1 to day 5. Addition of $T_{3}(10 \mathrm{nmol} / \mathrm{l})$ had no effect for the first 2 days of culture, but there was an increase in sIL-2R in the culture supernatant from the 3 rd day onward in preliminary experiments. PBMC were therefore cultured for 3 days with various concentrations of $T_{3}$ in the presence or absence of Con A in the subsequent experiments. There was a significant increase in sIL-2R when PBMC were cultured in the presence of Con $\mathrm{A}(5 \mu \mathrm{g} / \mathrm{ml})$ and various concentrations of $\mathrm{T}_{3}(1 \mathrm{nmol} / \mathrm{l} ; \mathrm{p}<0.05$, and 5, 7.5, $10,100 \mathrm{nmol} / \mathrm{l} ; \mathrm{p}<0.01$, respectively), and the peak sIL-2R level was reached at a $T_{3}$ concentration of 7.5 nmol/1 (Fig. 1). Addition of $\mathrm{T}_{3}$ had no effect on the increase in sIL-2R in the absence of Con $A$. In addition, sIL-2R was not detected in the culture

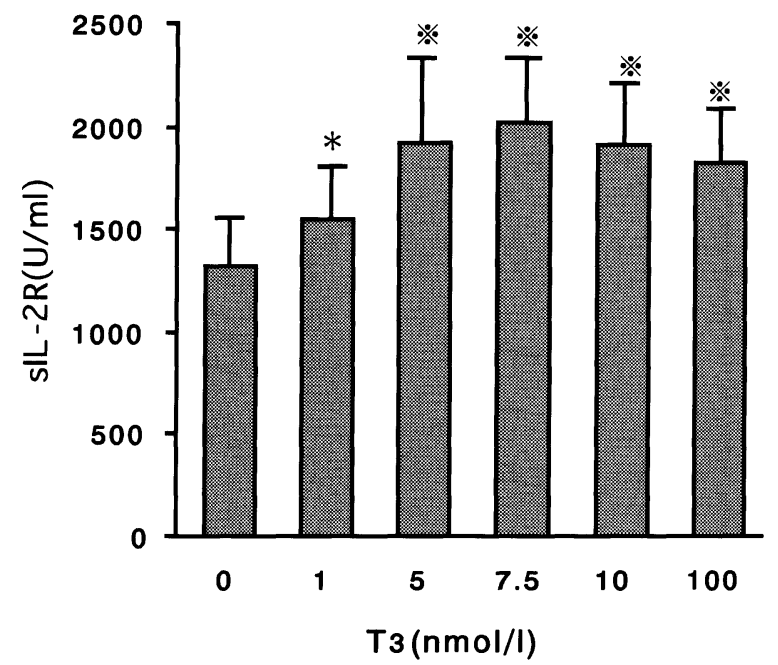

Fig. 1. SIL-2R alpha chain levels in culture supernatant. PBMC from normal volunteers were cultured for 3 days with Con A $(5 \mu \mathrm{g} / \mathrm{ml})$ and $\mathrm{T} 3$ at a various concentrations. paired $t$ test; $* \mathrm{p}<0.05$ vs. no $\mathrm{T}_{3}$ $(n=6), ※ p<0.01$ vs. no $T_{3}(n=6)$

supernatant when YT cells were incubated with IL-2 alone.

\section{Cell surface $I L-2$ receptor alpha chain expression by $P B M C$}

We examined cell surface IL-2R expression by direct flowcytometry to determine the mean fluorescence intensity (MFI). IL-2R expression by PBMC cultured with Con A plus $T_{3}$ reached a peak at $T_{3}$ concentrations from 7.5 to $10 \mathrm{nmol} / 1$. When PBMC were cultured with Con A $(5 \mu \mathrm{g} / \mathrm{ml})$ plus $\mathrm{T}_{3}(10$ nmol/l) for 3 days, the MFI was higher than when PBMC were cultured without $\mathrm{T}_{3}$, but the increase was not significant (Fig. 2). In cultures containing both Con A ( $5 \mu \mathrm{g} / \mathrm{ml})$ and IL-2 $(1 \mathrm{U} / \mathrm{ml})$, however, the increase of IL-2R was significantly $(p<0.05)$ greater in the presence of $T_{3}$ than in the absence of $\mathrm{T}_{3}$ (Fig. 2).

\section{IL-2 receptor alpha chain expression by YT cells}

We used YT cells to investigate the mechanism underlying the induction of IL-2R alpha chain expression by $T_{3}$. YT cells showed increased IL-2R expression after addition of IL-2 to cultures, and the level of IL-2R expression reached a plateau at IL-2 concentrations $>0.1 \mathrm{U} / \mathrm{ml}$ after 48 hours, and it also 


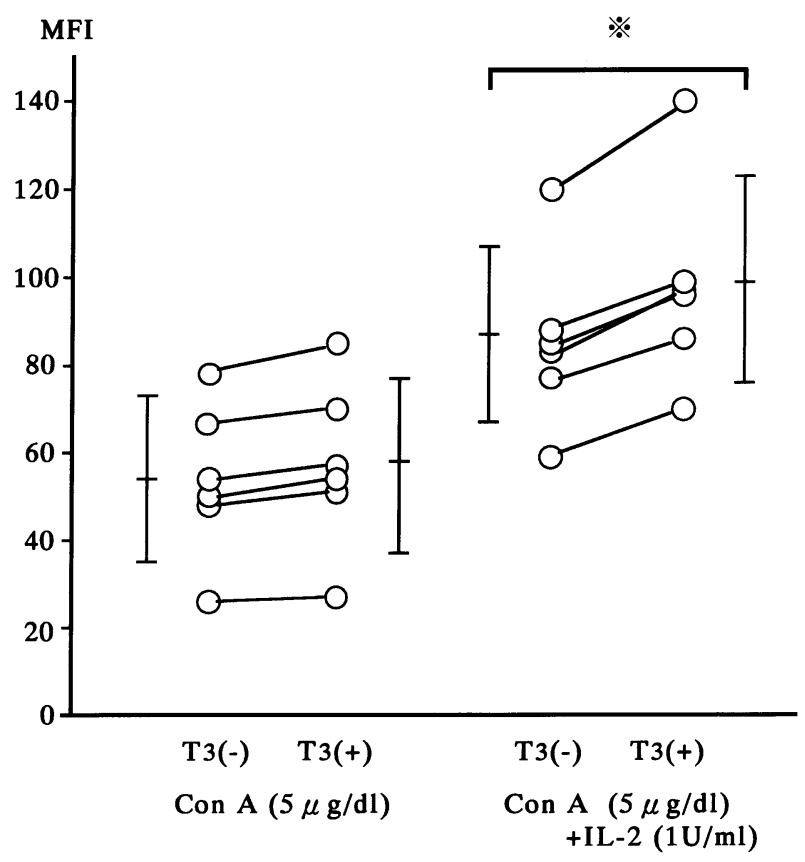

Fig. 2. Cell surface IL-2 receptor alpha chain expression by PBMC. PMBC were cultured for 3 days with Con A $(5 \mu \mathrm{g} / \mathrm{ml})$ alone (left panel) or Con A $(5 \mu \mathrm{g} / \mathrm{ml})$ plus IL-2 $(1 \mathrm{U} / \mathrm{ml})$ (right panel) in the presence or absence of $\mathrm{T}_{3}(10 \mathrm{nmol} / \mathrm{l})$. Anti-IL-2R binding is shown as the mean fluorescence intensity (MFI) of the entire histogram. Wilcoxon test $; \circledast \mathrm{p}<0.05$ vs. no $\mathrm{T}_{3}$ $(n=6)$

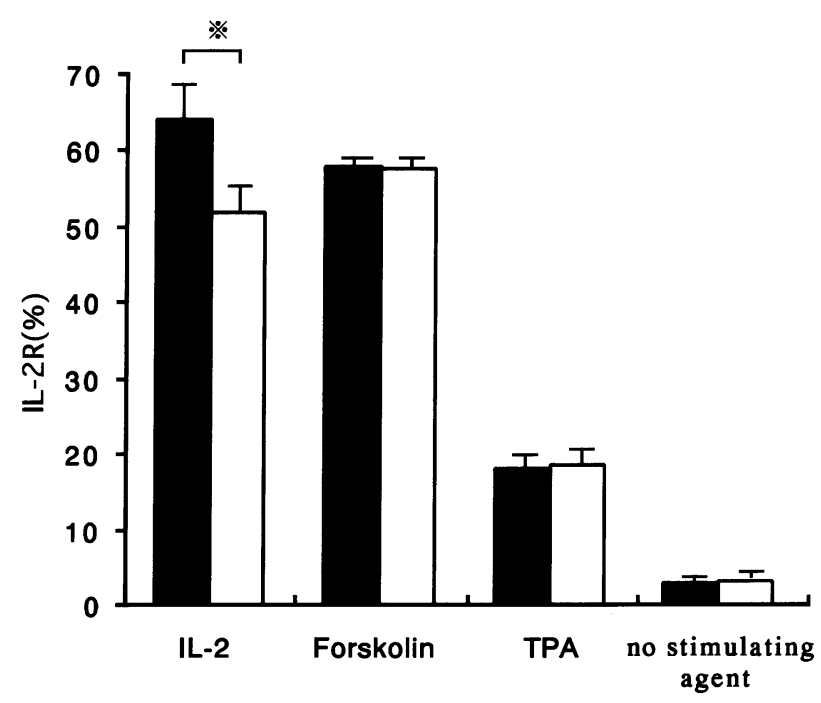

Fig. 3. Cell surface IL-2 receptor alpha chain expression by YT cells. Cells were cultured in the presence (closed columns) or absence (open columns) of $T_{3}$ (10 $\mathrm{nmol} / \mathrm{l})$ with IL-2 $(1 \mathrm{U} / \mathrm{ml})$, forskolin $(10 \mathrm{nmol} / \mathrm{l})$, TPA $(10 \mathrm{ng} / \mathrm{ml})$, or no stimulating agent. paired $t$ test; $※ p<0.01$ vs. no $T_{3}(n=6)$ reached a peak in the presence of $10 \mathrm{nmol} / 1 \mathrm{~T}_{3}$. IL-2R expression was significantly $(p<0.01)$ greater in the presence of $\mathrm{T}_{3}$ plus IL-2 $(1 \mathrm{U} / \mathrm{ml})$ than in cultures with IL-2 alone (Fig. 3). In cultures with TPA $(10 \mathrm{ng} / \mathrm{ml})$, approximately $20 \%$ of the cells were IL$2 \mathrm{R}$-positive after 24 hours, but the positivity rate decreased to $9 \%$ and $4 \%$ after 48 and 72 hours, respectively. IL-2R expression was also increased by culture with forskolin $(10 \mu \mathrm{mol} / \mathrm{l})$, being approximately $66 \%$ and $54 \%$ after 24 and 48 hours. We examined whether $\mathrm{T}_{3}$ had an influence on IL-2R expression when added together with TPA, or forskolin, or without any stimulating agent, but found no change in the presence of $T_{3}$ (Fig. 3).

\section{Proliferative response to $I L-2$ and/or Con $A$}

There was no significant change in thymidine incorporation after the addition of $\mathrm{T}_{3}$ to PBMC stimulated with Con A alone or with Con A plus IL-2, and YT cells stimulated with IL-2 (data not shown).

\section{Discussion}

The present study showed that a thyrotoxic state induced by exposure to $T_{3}$ resulted in augmentation of IL-2R alpha chain expression by YT cells and Con A-stimulated PBMC cultured in the presence of IL-2. This enhancement of IL-2R alpha chain expression by $T_{3}$ reached a peak at $T_{3}$ concentrations from 7.5 to $10 \mathrm{nmol} / \mathrm{l}$, corresponding to the serum $\mathrm{T}_{3}$ concentration range in patients with untreated Graves' disease [15].

There have been several previous reports regarding the influence of thyroid hormone on the immune system [3-7]. $T_{3}$ enhances the production and secretion of thymulin, which is a thymic hormone with an important role in $\mathrm{T}$ cell development and function [3]. The IL-2/IL-2R system plays a central role in immune function by participating in the activation of $\mathrm{T}$ cells and by stimulating their proliferation $[10,11]$. Therefore, if thyroid hormone influences IL-2/IL-2R expression, it may modify immune function. But $T_{3}$ does not alter IL-2R alpha chain expression in rats [5], and we have also found that cell surface expression of the IL-2R alpha chain was not changed by administration of $T_{3}$ alone to 
Graves' disease patients in remission (unpublished observation). Of course, these findings were obtained after administration of $\mathrm{T}_{3}$ alone without any lectin or IL-2. If both IL-2 and $\mathrm{T}_{3}$ were administered simultaneously, expression of the IL-2R alpha chain might be increased, as occurred in our in vitro experiments or in studies on lectin-activated splenocytes of Xenopus laevis and Cornell $\mathrm{K}$ chickens $[12,13]$.

Since the sIL-2R level and IL-2R alpha chain expression were not influenced by $T_{3}$ when PBMC were cultured without Con A, or YT cells were cultured without IL-2, this hormone did not have a direct effect on expression of the IL-2R alpha chain, but $\mathrm{T}_{3}$ seems to act as a copromoter of IL-2R alpha chain expression in the presence of IL-2, because IL-2R alpha chain expression was superinduced by the simultaneous addition of IL-2 and $T_{3}$. Con Astimulated PBMC also contain monocytes, so some interaction between accessory cells and $\mathrm{T}$ cells or the products of accessory cells may be related to the augmentation of IL-2R alpha chain expression by $T_{3}$. But YT cells exposed to $T_{3}$ also showed superinduction of IL-2R alpha chain expression, suggesting that $T_{3}$ may be directly involved in the process of the IL-2R alpha chain expression. Forskolin and TPA also induced IL-2R alpha chain expression by YT cells. Forskolin activates adenylate cyclase and TPA activates protein kinase $C[24,25]$, whereas IL-2 activates tyrosine kinase via the IL-2R [26] to enhance IL-2R alpha chain expression. These differences in the signal transduction pathways of IL-2, forskolin and TPA may explain why the effect of $T_{3}$ on IL-2R enhancement was only noted in the presence of IL-2.

The high-affinity IL-2R consists of three subunits (the alpha, beta, and gamma chains). Both the beta and gamma chains are responsible for signal transduction and cell growth [10,11], and the absolute number of high-affinity receptors per cell is limited by the levels of these two chains. As thymidine incor- poration did not change in the presence or absence of $T_{3}$ in our experiments, $T_{3}$ may have no influence on the expression of these two chains. This conclusion is compatible with the report that expression of the transferrin receptor, which is induced on cells in the late G1 phase and is essential for DNA synthesis and cell growth [27], is unchanged by the administration of $T_{3}$ to rats with hyperthyroidism [5].

Although the IL-2R alpha chain is only a lowaffinity receptor itself, it plays an important role in formation of the high-affinity receptor [11]. IL-2R alpha chain overexpression relative to the level of high-affinity receptors may be beneficial for the autocrine system when cells are cultured at low densities [28]. Even if IL-2R alpha chain expression is superinduced by $T_{3}$, the high-affinity receptor level may not change at a cell density of $10^{6} / \mathrm{ml}$, as was used in our experiments, but when the IL-2R alpha chain is superinduced in a setting where the autocrine system is active such as in the thyroid gland, formation of high affinity-receptors may show a marked increase.

The abnormalities of lymphocytes infiltrating the thyroid gland in patients with autoimmune thyroiditis are generally thought to result from the primary autoimmune mechanism involved in the pathogenesis of this disease [29]. Nevertheless, our findings indicate that $T_{3}$ may modify the immune system by altering IL-2R alpha chain expression, and this suggests that hyperthyroidism may itself be a selfperpetuating factor in the progression of Graves' disease through activation of the IL-2/IL-2R system, although the precise mechanism involved and its role in immune regulation remain unknown.

\section{Acknowledgments}

The technical assistance of Mr. Kameda in (flowcytometry) and Mr. Oka (cell culture) is also gratefully acknowledged.

\section{References}

1. George E. Shambaugh (1986) Biological and cellular effects. In: Braverman LE, Utiger RD (eds). Werner and Ingbar's-The thyroid-A fundamental and clinical text. J. B. Lippincott Company, Philadelphia, 6th ed.: 201-218.
2. Michie W, Swanson BJ, Mahaffey RG, Honein EF, Fowler GB (1967) Quantitative radiological and histological studies of the thymus in thyroid disease. Lancet i: 691-695.

3. Fabris N, Moccheginani E, Mariotti S, Pacini F, 
Pinchera A (1986) Thyroid function modulates thymus endocrine activity. J Clin Endocrinol Metab 62: 474-478.

4. Pacini F, Nakamura H, DeGroot LJ (1983) Effect of hypo- and hyperthyroidism on the balance between helper and suppressor T cells in rats. Acta Endocrinol 103: 528-534.

5. Ohashi H, Itoh M (1994) Effects of thyroid hormones on the lymphocyte phenotypes in rats: Changes in lymphocyte subsets related to thyroid function. Endocrine Regulations 28: 117-123.

6. Provinciali M, Muzzioli M, Stefano GD, Fabris N (1991) Recovery of spleen cell natural killer activity by thyroid hormone treatment in old mice. Nat Immun Cell Growth Regul 10: 226-236.

7. Rittenhouse PA, Redei E (1997) Thyroxine administration prevents streptococcal cell wall-induced inflammatory responses. Endocrinology 138: 14341439.

8. Weetman AP, McGregor AM, Ludgate M, Hall R (1984) Effect of triiodothyronine on normal human lymphocyte function. $J$ Endocr 101: 81-86.

9. Weetman AP, Mcgregor AM, Rennie DP, Hall R (1982) Thyroid hormones fail to influence experimental autoimmune thyroiditis. Clin Exp Immunol 50: 51-54.

10. Smith KA (1989) The interleukin 2 receptor. $A$ Rev Cell Biol 5: 397-408.

11. Waldmann TA (1993) The IL-2/IL-2 receptor system: a target for rational immune intervention. Immunol Today 14: 264-270.

12. Ruben LN, Chothier RH, Murphy GL, Marshall JD, Lee R, Pham T, Nobis C, Shiigi S (1989) Thyroid function and immune reactivity during metamorphosis in Xenopus laevis, the South African clawed toad. General and Comparative Endocrinology 76: 128138.

13. Chandratilleke D, Hala K, Marsh JA (1996) Effects of in vivo thyroid hormone treatment on the expression of interleukin-2 receptors on avian splenocytes. Int $J$ Immunopharmac 18: 203-210, 1996.

14. Rubin LA, Kurman CG, Fritz ME, Biddison WE, Boutin B, Yarchoan R, Nelson DL (1985) Soluble interleukin-2 receptors are released from activated human lymphoid cells in vitro. J Immunol 135: 3172-3177.

15. Nakanishi K, Taniguchi Y, Ohta Y (1991) Increased soluble interleukin-2 receptor levels in autoimmune thyroid disease. Acta Endocrinol 125: 253-258.

16. Yasuda N, Patrick KL, Stephen HI, Patrick CK, Himura Y, Matsuoka M, Hattori T, Takatsuki K, Purtilo DT (1988) Soluble interleukin-2 receptors in sera of Japanese patients with adult $\mathrm{T}$ cell leukemia mark activity of disease. Blood 71: 1021-1026.
17. Yamaguchi S, Onji M, Ohta Y (1988) Increased serum soluble interleukin-2 receptor levels in patients with viral liver disease. Hepatogastroenterol 35: 245-248.

18. Chow CG, Lai KN, Leung JCK, Chan JCN, Cockram CS (1990) Serum soluble interleukin-2 receptor in hyperthyroid Graves' disease and effect of carbimazole therapy. Clin Endocrinol 133: 317-321.

19. Mariotti S, Caturegli P, Barbesino G, Marino M, Del Prete GF, Chiovato L, Tonacchera M, De Carli M, Pinchera A (1992) Thyroid function and thyroid autoimmunity independently modulate serum concentration of soluble interleukin-2 (IL-2) receptor (sIL-2R) in thyroid diseases. Clin Endocrinol 37: 415422 .

20. Yodoi J, Teshigawara, Nikaido T, Fukui K, Noma T, Honjo T (1985) TCGF (IL-2)-receptor inducing factor(s). Regulation of IL-2 receptor on natural killer like cell line (YT cells). J Immunol 134: 1623-1630.

21. Scholz W (1990) Synergistic induction of interleukin2 receptor (TAC) expression on YT cells by stimultaneous activation of distinct signal transduction pathways. Cellular Immunol 125: 284-290.

22. Robb RJ, Rusk CM, Yodoi J, Greene W (1987) Interleukin-2 binding molecule distinct from the Tac protein: Analysis of its role in formation of high-affinity receptors. Proc Natl Acad Sci USA 84: 2002-2006.

23. Samuels HH, Stanley F, Casanova J (1979) Depletion of L-3,5,3'-triiodothyronine and L-thyroxine in euthyroid calf serum for use in cell culture studies of the action of thyroid hormone. Endocrinology 105: 80-85.

24. Seamon KB, Padgett W, Daly JW (1981) Forskolin: Unique diterpen activator of adenylate cyclase in membranes and in intact cells. Proc Natl Acad Sci USA 78: 3363-3367.

25. Castagna M, Takai Y, Kaibuchi K, Sano K, Kikkama U (1982) Direct activation of calcium-activated, phospholipid-dependent protein kinase by tumorpromoting phorbol esters. J Biol Chem 257: $7847-$ 7851.

26. Taniguchi $\mathrm{T}$ (1995) Cytokine signaling through nonreceptor protein tyrosine kinases. Science 268: 251-255.

27. Neckers LM (1991) Regulation of transferrin receptor expression and control of cell growth. Pathobiology 59: 11-18.

28. Forsten KE, Lauffenburger DA (1994) The role of low-affinity interleukin-2 receptors in autocrine ligand binding: Alternative mechanisms for enhanced binding effect. Molecular Immunol 31: 739-751.

29. DeGroot LJ, Quintants J (1989) The causes of autoimmune thyroid disease. Endocrine Rev 10: 537-562. 